\title{
18. The role of the state in the development of social services Margitta Mätzke
}

\section{INTRODUCTION}

This book has explored the current situation and ongoing developments in a number of publicly funded social service fields and in several European countries, regions and cities. Discursively an element of social investment strategies (see the opening chapters by Martinelli and by Gómez-Barroso et al., in this volume), social services are gaining importance, as social needs are multiplying and resources for informal family care are becoming increasingly scarce. Austerity policies in the large cash transfer schemes of many European welfare states add to the burden that has to be shouldered by social services (Sirovátka, 2016). With their highly individualised in-kind benefits, social services often address needs that have fallen through the cracks of more mainstream, often insurance-based cash transfer schemes (Spicker, 2013; Sachße, 2011). At the same time, much of that enhanced role is wishful thinking more than reality (see Bode, in this volume), as many public social services are under siege. While called on to respond to growing and increasingly diverse needs, they have to do so under conditions of more precarious resource bases and working conditions.

Together the chapters in this volume have presented a vivid picture of the changing landscape of social services in Europe. The analyses are based on case studies that were shared in the course of the COST Action IS1102 SO.S. COHESION - Social services, welfare states and places. They compare and synthesise the insights gained from these case studies from a variety of different substantive angles and theoretical perspectives. The emerging picture is thus necessarily variegated - a mosaic of images and interpretations, based on observations from a variety of different social service fields, countries, initiatives, actors involved in social service provision, or institutional characteristics of social service infrastructures.

Nonetheless, a shared theme has emerged from this mosaic. All chapters in this volume are aware of significant changes in the role of the public sector in social services, and they are all keenly attentive to the potential 
drawbacks and problematic aspects of the changing outlook of public policy engagement. This chapter seeks to understand the underlying commitments and building blocks of this critical assessment. To do so, it will first highlight the dominant tendency and policy development as it was observed in many of the preceding chapters. It will then think through the implications of this trend for the interpretation of the overall character of social services and pinpoint the criteria motivating the problematising and wary outlook on the changing social service landscape that is often expressed throughout the book. The concluding section revisits the question of how to think about public sector involvement in social services and points out how important it is to consider the details of implementation and the specific institutional settings and contextual factors of social service design when appraising the role of the state in social services.

\section{SOCIAL SERVICE DEVELOPMENT DESCRIBED: A SHARED THEME WITH VARIED MANIFESTATIONS}

As highlighted above, this book has embraced diversity: the chapters have different theoretical angles and thematic perspectives, and they cover a range of different social service fields and national contexts. As in many institutionally complex settings, path dependence is inherent in the trajectories (Pierson, 2000), so that diverse observations about policy developments come as no surprise. Notwithstanding this variety, however, the chapters have identified a main trend that is shared across contexts and thematic fields, and this is a tendency of central governments to turn their back on their traditional commitments to providing a social service infrastructure for all citizens in need. In fact, universal access to social services has been a desideratum rather than a reality in most countries, but access to publicly provided social care for those in need has been widely shared as a policy goal and moral ambition. It has inspired institutional development, since social services, with their focus on individualised needs at given points in people's life course, have been considered a catalyst of social integration and by that token an aspect of social citizenship in many countries and with regard to many areas of social care. It is this social citizenship rights-based commitment to public social services that governments in Western democracies are abandoning to a certain extent.

There is no universal tendency toward 'state withdrawal' from social policy, however. Changes in the role of the state vary in pace and form; there are no 'strong' or 'weak' states in terms of their role as welfare producers, only different manifestations of welfare state interventionism, 
which have evolved over time (Mätzke, 2011). We are not witnessing the 'decline of the state', but we do observe changing priorities of public policy intervention (Baldwin, 2005a) as well changing policy approaches (Baldwin, 2005b). Policy changes in the social service field are pointing in roughly similar directions, however: the activist role of the public sector as provider, organiser and financer of social services is increasingly contested, as are ideas of comprehensive public responsibility for ensuring citizens' well-being and social security. Instead, central government policy-making is relegated to its indirect and regulatory role, while social service provision and governance are often devolved to decentralised agencies or non-state organisations. It is in that sense, and as we will see below with reference to a specific set of norms, that the chapters in this book diagnose something that we like to call 'public sector disengagement'. This 'public sector disengagement' and the shifts in tasks and responsibilities are manifest in 'vertical' and in 'horizontal' directions, and there are several public policy changes to fuel the tendencies (see also Martinelli, Chapter 1, in this volume).

\section{Disengagement of Central Governments as Decentralisation in a Setting of Chronic Underfunding}

Responsibility for not only providing, but to an increasing extent also planning and financing social services has been shifting back to the local level. Hence, innovative local initiatives have become increasingly important and counted on by central government policy-makers, as there is often no additional national funding for the increasing scale of local activity, only the pressure of needs and responsibilities. Depending on the field of social services, central governments may continue to play a central role enacting framework legislation about availability of, sometimes even entitlement to, certain social services, regulating the supply and monitoring quality. But this is not always the case, and making social services available, funding them, providing the infrastructure and employing the staff is often (and increasingly so) declared a responsibility of municipalities (see Sabatinelli and Semprebon and Mas Giralt and Sarlo, in this volume). Developing and testing innovative forms of care service provision is also left to municipalities (see Kubalč́́ková et al.; Häikiö et.al. and Brokking et al., in this volume), and more often than not there is little more than rhetorical support for such local initiatives. In a sense social services have come full circle in their development, as almost all fields of social care have historically started at the municipal level (Sachße, 2011; Rathmayr, 2014), often as third-sector initiatives, in the context of local poor relief programmes. During the twentieth century, social policy had moved beyond isolated 
local initiatives and welfare state expansion in the social service field took the form of upward rescaling (see Sabatinelli and Semprebon, in this volume). There is now, therefore, an expectation of national standards for local social services and the definition of some minimal provisos helping local governments to live up to these standards. If this is not forthcoming, the impression that decentralisation is a form of retrenchment is not too far-fetched.

A process closely related to this trend toward decentralised service provision is de-institutionalisation. De-institutionalisation involves moving social care out of specialised organisations such as nursing homes or formal childcare facilities and back into informal settings. It may also merely entail the reduction of the size of organisations that provide care (see Anttonen and Karsio; Deusdad, Lev et al. and Kubalč́ková et al., in this volume). It usually goes along with a greater role of private providers, and generally social service systems that are more complex and opaque in their structures of governance and supply (see Anttonen, in this volume). But de-institutionalisation is also the tendency that is least generalisable across different social service fields: it is rather pronounced in social care for older people, where the goal of 'ageing in place' has become an important objective in social service design, whereas in the field of childcare, or in social assistance services (see Raeymaeckers et al., in this volume), policy developments have been pointing in the opposite direction of a greater amount of institutionalisation (and even public involvement).

\section{Disengagement of the Public Sector and the Growing Importance of Non-state Actors}

Three processes account for a growing importance of non-state actors in social service fields (see also Leibetseder et al., in particular Table 6.2, in this volume). The first is the growing importance of social care services provided by for-profit, private sector providers that can be observed in some policy fields and some countries (see Anttonen and Karsio, in this volume). Sometimes this takes the form of semi-formal 'grey' markets (see Kubalčíková et al., in this volume); some other times the private sector is explicitly endorsed by the state as institutional structure for supplying and governing social care services, amounting to what some observers call 'combining' public and private resources (Sirovátka and Greve, 2016a). The second process through which governments transfer responsibilities to non-state actors involves third-sector organisations (non-profit providers) or actors of organised civil society, such as private welfare associations or charities. This also entails quite explicit expectations of volunteer work and local initiatives of social innovation (see Häikiö et al.; Weinzierl et al. and 
Brokking et al., in this volume), but overall within institutional frameworks that are much more volatile and complex than third-sector social service provision has traditionally been (see Bode, in this volume and Bode, 2006). Thirdly, families and informal care arrangements are explicitly enlisted as providers of social care. While large parts of social care have always been provided in informal settings and by private actors of various description (Sachße, 1994; 2011), in the second half of the twentieth century the social service systems of many countries had been moving away from an exclusive reliance on families and other non-state actors. Recent developments in many areas of social care have been pointing in the opposite direction, of (re-) endorsing informal care arrangements and counting on families in meeting the needs for social care in contexts of shrinking public resources and involvement, either intentionally or by default.

The chapters in this volume diagnose disengagement of the state mainly with regard to the provision and financing of social services, much less so with regard to legislation setting up general goals and regulatory frameworks concerning access and quality (see also Klenk and Pavolini, 2015). Attempts at state disengagement were at times driven by ideological convictions, being part of a 'neo-liberal turn' and an agenda that pictures a smaller role of public policy in economic and social affairs; more often than not there was not much of a political agenda involved, and the driving force was budgetary strain and the mere wish to cut costs by shedding responsibility for expensive and expanding tasks.

Given the diversity of settings, countries and thematic fields in which social services are delivered, the shared theme of "public sector disengagement' manifests itself in different forms (see Kröger and Bagnato, in this volume, for a description of the ranges of policy approaches in a number of substantive dimensions). Even when disregarding the detailed substantive issues and searching for generalised trends, the shared themes are hidden behind diversity. In many countries and policy fields fiscal austerity in the wake of the 2008 financial crisis accelerated developments that had already evolved in the directions described above. This is certainly the case for some of the Nordic countries (Finland especially; see Anttonen and Karsio, in this volume). Some other countries, such as Germany or Austria, experienced much less fiscal strain to begin with, yet the regime of fiscal discipline that was installed in response to the euro-crisis provided the justification for intensifying older agendas of public sector retrenchment. In yet another geographic setting, the Mediterranean countries, the euro-crisis and its aftermath interrupted developments in which these southern European countries were in a process of 'catching up' - at least in legislative terms - with their richer northern European neighbours. With regard to this process one could argue that the euro-crisis has led 
to a resurgence of the old North-South divide that Europe was in the process of slowly closing before the crisis hit (see the concluding chapter by Martinelli, in this volume).

In some social service fields and countries, such as care for older people, the social inclusion of immigrants or other vulnerable groups, the tendencies toward state disengagement through underfunding or devolution of tasks can be observed very clearly, and the chapters in this volume describe the complex settings of informal and/or private sector delivery that result from these trends. In other fields, such as childcare and, perhaps, social assistance services or healthcare, the dominant trend in many countries has been one of greater public sector involvement, at times even greater central government intervention (Greer and Mätzke, 2015; Sirovátka and Greve, 2016b; Hora and Sirovátka, 2016). However, even here direct public sector provision takes second place behind outsourcing, and sometimes cash vouchers, albeit within a growing regulatory framework set by public authorities (Klenk and Pavolini, 2015; Pierson, 2007).

\section{EXPLORING POLICY IMPLICATIONS: SOCIAL SERVICES DISRUPTED}

If policy development takes different forms in different settings, then the heterogeneity of socioeconomic contexts, specific social service needs and resources to address these needs will also produce a great variety of specific impacts on service quality and access, with the emergence of relevant patterns of inequality across these different settings. Rather than portraying all these differences, the following remarks will think through the implications of the developments described above for the general character of social services in the European polities and societies. In this respect, I submit, the chapters of this volume paint a picture that is surprisingly consistent across the many specific findings and interpretations.

We refer to this consistent theme as 'disruption'. In our context disruption pertains to an erosion of the traditional commitment of public social policy, including social services. Even if this was nowhere fully realised, it still postulates something like the normative core of a 'New Liberal' (Katznelson, 1996), or social citizenship-based, progressive agenda in welfare state and more specifically social service development. Many social policy observers or practitioners subscribe to such an agenda, and from the perspective of this agenda discern undesirable traits in recent developments of social service fields. Following Thomas H. Marshall's (1950) lead, the agenda stipulates entitlement to a minimum standard of social care, if needed, as a privilege that comes with citizenship - a membership right, 
not contingent on a quid pro quo (Somers, 2008). This citizenship conception of social rights insists on the important role of the public sector in supplying and financing social services. It holds that membership rights and recognition are complementary features, not alternatives, to a notion of social rights that would focus on redistribution and income transfers (Fraser, 2001; Fraser and Gordon, 1994). In terms of policy implications, this citizenship idea of social service provision informs our authors' keen understanding of the disruption caused by public sector disengagement and the recent tendency to adopt market elements and commercial logics in the design and distribution of social services (Cox, 2000; Katz, 2001).

There is a lot of trust in the professionalism and expertise of public sector employees (Hood, 1995) and an overall positive appraisal of the long-term historical trajectory of publicly provided service infrastructures and social benefits (see Steinmetz, 1993, who labels this perception of social policy improvement a 'whig narrative' of the welfare state). In historical perspective, the 'darker' side of early social policy intervention has not gone unnoticed and many historiographic accounts have pointed out the repressive traditions of local poor relief (Sachße, 2011; Rathmayr, 2014; Sachße and Tennstedt, 1986). Emancipation and professional development, along with broadened access and dropping many of the old poor-relief lineages are the building blocks of a story of social service modernisation often told. It forms the backdrop against which the recent transformation - from public service to public management (Gray and Jenkins, 1995) - is often eyed with reservation. Some observers are worried about a decline of professional norms and public service ethos (Schimank, 2015; more moderately: Noordegraaf, 2015), others are critical of possible repercussions of market logics for quality and availability of social services, and still others fear new forms of exclusion or a new 'welfare paternalism' (Soss, 2005; Evers, 2008) to result from marketisation and managerialism.

The citizenship concept of social rights has not only informed much of the scholarly debate about social services in welfare state development and public policy more generally (see Mätzke et al., in this volume; Rothstein, 1998; Somers, 2008); it has also defined normative guidelines and a benchmark for evaluating the observations about specific social services, which this volume's authors have all subscribed to in one way or another. This benchmark comprises a combination of three core objectives, and we talk about 'social services disrupted' when one or more of these core objectives are severely compromised. In those cases, social service systems can still serve beneficial ends, there may still be promising developments and many good justifications for new approaches in the design and governance of social services, but they are not inspired by the idea of providing social services as aspects of social citizenship rights. Evaluating such new 
approaches becomes more volatile and potentially more arbitrary, because it lacks the clear normative reference point that the citizenship conception of social rights has provided. The citizenship conception is defined by the combination of three core commitments:

1. Inclusiveness (as shaped by access and affordability). Entitlement to use certain services is determined by need; it does not have to be earned (Somers, 2008; Katz, 2001). There may be needs tests, and there may be targeting and positive discrimination, but access to social services is not based on privilege, certain behaviours or preconditions, and in that sense an egalitarian spirit almost always informs (citizenship-based) social service provision (Anttonen et al., 2012).

2. Equal entitlement in terms of the substantive content of what is provided. Quality and the scope of services should not be contingent on who needs them and where persons in need live. Professionalism among providers is to secure ensure quality (Noordegraaf, 2015; Hood, 1995); central government coordination seeks to install territorial cohesion.

Taken together, these first two points amount to what Anttonen (Chapter 17 , in this volume) defines as universalistic social service design.

3. Users' self-determination and empowerment. These are important goals in social service design (Spicker, 2013) and social policy at large. Esping-Andersen (1990) has emphasised the emancipatory potential of the welfare state, while with regard to social services, autonomy (as independence of market income as well as family support) is a central evaluative category. In a citizenship conception of social rights, services are there to assist people (to avoid dependence and allow users to lead the lives that they choose as much as possible); their purpose is not to discipline them. Many service institutions do just that, however, so instrumentalist and paternalistic traits are entrenched in many social services (Anttonen et al., 2012), and autonomy is often a myth. But from the perspective of a citizenship-based conception of social rights it is a myth and a moral ambition, and as such has informed the way the authors in this volume have judged the policies and the developments that they have observed.

Together this set of core commitments echoes salient themes in scholarly debates about welfare state development (Rothstein, 1998; Somers, 2008), such as the role of social benefits, including social services, in defining patterns of inequality and exclusion (Esping-Andersen, 1990; 
Ingram and Schneider, 2005) as well as the emancipatory role that social policy may or may not play, depending on how it is designed (see Mätzke et al., in this volume). It also reflects an agenda that motivates actors and decision-makers in particular social service fields and fuels their attempts at promoting social inclusion and equal social rights by providing highly individualised in-kind services and social work, especially for vulnerable groups that tend to fall through the cracks of insurance-based cashtransfer systems. It finally expresses a third major aspiration of many practitioners and analysts of social policy, namely the commitment to autonomy, in which (public) social services help people to lead the lives they want (Anttonen and Sipilä, 1996), rather than the lives that fit into some organisational logic conveniently.

To thrive as progressive agenda, the citizenship-based conception needs all three core commitments to be largely intact: a country can have universalistic systems of services and include everyone on equal footing, but still fall short on the commitment to autonomy, so that its public social services are hardly emancipatory and may even increase the number of limitations and arbitrary rules that users may be confronted with when they use social services. Likewise, countries may have social services systems strongly committed to preventing dependency and promoting autonomy, and these systems may even be open to everyone. If the quality and the scope of services offered vary wildly across who needs help and where they live, then entitlement is a matter of chance at best and a matter of privilege at worst. Finally, countries can design benefit schemes intended to enhance autonomy and empower all users on equal footing, but if access is contingent on long lists of preconditions that especially vulnerable groups in society often find difficult to fulfil, then much of the empowering and egalitarian thrust will run aground, and social service fields become just another structure of social exclusion.

What the chapters in this volume show is that disengagement of central government commitment to social services very often entails one or two of the dimensions falling short. Social service sectors could then still evolve on relatively stable trajectories; they may even enjoy increasing amounts of public resources and attention. Yet one would need to regard these trends with suspicion nevertheless, and more often than not diagnose troublesome trends: 'tragic moments', 'illiberal' service designs, Potemkin villages in which empowerment, equality and social inclusion reside in political rhetoric, not reality, and social service sectors that promise more than they can deliver by way of citizenship-based entitlement. In these instances, this book speaks of disruption - not necessarily because organisations, regulatory structures or funding sources are in total disarray, but because core normative commitments of social service supply are compromised: access 
to social services is losing its character as a facet of social citizenship rights and in that sense it is disrupted. Against the backdrop of this citizenship conception of social rights the authors in this volume have a hard time painting an unequivocally benign picture of social service development and instead point to a range of pitfalls and potential dangers of ongoing trends.

- The loss of stable public funding guarantees produces volatile and ultimately unreliable project-forms of social service provision that are often at odds with the nature and time frame of needs, prove unsustainable over time and may evolve into highly uneven and unequal patterns of access (Bode, 2006).

- Decentralisation along the territorial axis and excessive reliance on non-public provision has similar fragmenting effects, likewise producing both selective access and conditional entitlement. They have also the potential to produce and reproduce inequality and exclusion.

- Competition and quasi-market elements in the governance systems of care services (both public and privatised) are often at odds with the capabilities of providers and, more gravely, users, potentially generating patterns of unequal access and exclusion among users, as well as barriers to access and favouritism among providers.

- The same holds for de-institutionalisation of social care, especially if this strategy is implemented without providing adequate financial resources and institutional support for the evolving structures of domiciliary care.

- Disengagement from public commitments in the provision and financing of social services, if they are split off from regulation and provision (Sirovátka and Greve, 2016a), finally bears the risk of losing control over the qualitative aspects of social care delivery as well. The tasks of regulating service provision and monitoring service quality tend to become harder when public authorities are not involved in social service delivery and when they are up against a set of non-state actors who may not share an agenda of social inclusion, equality and empowerment.

Most of the analyses in this volume have therefore ended on a critical note when assessing the implications of the social service developments they analysed. All the cases studies of policy development point out the potential dangers of the trends they have observed; all reports of local initiatives and instances of social innovation point out the difficulties in generalising and institutionalising the innovative and successful practices in times of fiscal austerity. One reason for this problematising undertone 
has been given here: it is the surrender of one or several of the traditional core commitments of social service policies that has often bothered the authors in this volume, because that signals a kind of disruption that has to be acknowledged and weighed against the good arguments and actual advantages of policy changes.

\section{CONCLUDING REMARKS: THE IMPORTANCE OF CONTEXT AND INSTITUTIONAL DETAIL}

A lesser amount of direct public delivery and, overall, a smaller presence of state guarantees, state intervention or state guidance in the provision of services is a major tendency that the contributions in this volume have identified. There are many arguments that suggest why this tendency is attractive from a policy perspective. Policies such as de-institutionalisation, decentralisation, or cooperation across the public-private divide hold the promise of promoting structures of social care delivery that can leave behind some of the cost driving and sometimes patronising aspects of the former public social service designs. Decentralised and non-state provided social care is often favoured by policy-makers, because it is seen as a form of social service organisation that allows users to exercise consumer choice. This, the argument goes, not only installs an element of market discipline, it also promotes autonomy and self-determination and thus contributes to the classical emancipatory agenda. A varied mix of service providers municipal service providers or ones run by third-sector organisations, forprofit or not-for-profit, formal or informal ones - allows for the diversity that makes choice meaningful and generates the expectation that providers are more responsive to people's needs, while allowing for social innovation and giving people in need of care the chance to define the kind of care arrangement they prefer (Sirovátka and Greve, 2016a).

When we take a closer look at all the preconditions that would be required for a scenario of 'public sector disengagement' to deliver such beneficial effects and become indeed the guarantor of autonomy and empowerment while preserving inclusiveness and equal entitlement, we become much more uncertain and wary of wholeheartedly embracing state disengagement. A 'progressive agenda' for citizenship-based social services would require the two dimensions of universalism - inclusive availability and equal entitlement - to be crucial elements in the assessment of social service designs. With regard to these two facets of universalism the problematic aspects of state disengagement stand out. Equality and access appear to be better served by retaining public involvement in what concerns both regulation and public financial support. Public control - in 
regulating and coordinating the delivery of social service infrastructures, in monitoring the quality of the services rendered and overseeing the training, professionalism and working conditions of care workers - is critically important for ensuring that social services are adequate and roughly equal for all citizens who need them. There must be substantive content to the definition of what should be available for all in need. Protecting that substance and its equitable distribution is a key function of public involvement. Only public funding and some measure of central government control over it can ensure the interregional transfers necessary to mitigate territorial disparities (see Sabatinelli and Semprebon; Martinelli, Chapter 19 , in this volume). Public financial support is also needed to keep social service systems broadly accessible and evenly available in the face of fiscal constraints, demographic strain and competitive pressures in a globalised economy.

Now public involvement does not necessarily mean public sector delivery. But public involvement does not mean a preference for non-state actors as providers, financers and regulators of social care either. As the detailed analyses of social service developments, initiatives in social innovation or policy alternatives throughout this book have demonstrated, institutional forms of social service fields alone do not determine the success or failure of progressive agendas. Contextual factors also matter, and what is needed as well is regulatory and administrative capacity on the part of central governments for implementing universalistic policies. Moreover, for a citizenship rights approach to social service design to become a reality one would also need governments intent on implementing universalistic and emancipatory agendas, rather than favouring social protection systems that enhance existing structures of privilege and social exclusion. Public sector involvement and influence of a democratically elected political centre is most valuable where democratic values and social citizenship norms are not completely lost on the people controlling that political centre (Somers, 2008). Sometimes it is indeed better to have decentralised governance structures, potent third-sector players and diversified structures of social service delivery, because those may serve as protective institutional layers and safeguards against reckless and injurious tampering with successful institutional designs.

Contextual factors, therefore, not only define the institutional preconditions that set policy development in motion on distinct trajectories. Their role is not merely to generate the resources and administrative capacities for enacting and implementing social policy agendas. Besides path dependence and political feasibility, contextual factors also shape intentions. Assessing policy alternatives, therefore, not only requires us to have a set of guidelines at our disposal that allow us to distinguish beneficial policy 
developments from the harmful ones. It also needs contextual knowledge of the kind that the contributions in this volume have supplied.

\section{REFERENCES}

Anttonen, A. and J. Sipilä (1996), 'European social care services: is it possible to identify models?', Journal of European Social Policy, 6 (2), 87-100.

Anttonen, A., L. Häikiö and J. Sipilä (2012), 'Universalism and the challenge of diversity', in A. Anttonen, L. Häikiö and K. Stefánsson (eds), Welfare State, Universalism and Diversity, Cheltenham, UK and Northampton, MA, USA: Edward Elgar Publishing, pp. 1-15.

Baldwin, P. (2005a), 'Beyond weak and strong: rethinking the state in comparative policy history', The Journal of Policy History, 17 (1), 12-33.

Baldwin, P. (2005b), Contagion and the State in Europe, 1830-1930, Cambridge: Cambridge University Press.

Bode, I. (2006), 'Disorganized welfare mixes: voluntary agencies and new governance regimes in Western Europe', Journal of European Social Policy, 16 (4), 346-59.

Cox, R.H. (2000), 'The consequences of welfare reform: how conceptions of social rights are changing', Journal of Social Policy, 27 (01), 1-16.

Esping-Andersen, G. (1990), The Three Worlds of Welfare Capitalism, Princeton: Princeton University Press.

Evers, A. (2008), 'Investiv und aktivierend oder ökonomistisch und bevormundend? Zur Auseinandersetzung mit einer neuen Generation von Sozialpolitiken', in A. Evers and R.G. Heinze (eds), Sozialpolitik: Ökonomisierung und Entgrenzung, Wiesbaden: VS-Verlag für Sozialwissenschaften, pp. 229-50.

Fraser, N. (2001), 'Recognition without ethics?', Theory, Culture and Society, 18 (2-3), 21-42.

Fraser, N. and L. Gordon (1994), 'Civil citizenship against social citizenship? On the ideology of contract-versus-charity', in B. van Steenbergen (ed.), The Condition of Citizenship, London, UK, Thousand Oaks, USA and New Delhi, India: Sage Publications, pp. 90-107.

Gray, A. and B. Jenkins (1995), 'From public administration to public management: reassessing a revolution?', Public Administration, 73 (Spring 1995), 75-99.

Greer, S.L. and M. Mätzke (2015), 'Health systems in the European Union', in E. Kuhlmann, R.H. Blank, I.L. Bourgeault and C. Wendt (eds), The Palgrave International Handbook of Healthcare Policy and Governance, Basingstoke: Palgrave Macmillan, pp. 245-69.

Hood, C. (1995), 'Emerging issues in public administration', Public Administration, 73 (Spring), 165-83.

Hora, O. and T. Sirovátka (2016), 'Employment in the health and social services: evidence and problems', in T. Sirovátka and B. Greve (eds), Innovation in Social Services. The Public-Private Mix in Service Provision, Fiscal Policy and Employment, London, UK and New York, USA: Routledge, pp. 21-54.

Ingram, H.M. and A.L. Schneider (2005), 'Public policy and the social construction of deservedness', in A.L. Schneider and H.M. Ingram (eds), Deserving and Entitled. Social Constructions and Public Policy, Albany: SUNY Press, pp. 1-28. 
Katz, M.B. (2001), The Price of Citizenship. Redefining the American Welfare State, New York: Metropolitan Books.

Katznelson, I. (1996), 'Knowledge about what? Policy intellectuals and the New Liberalism', in D. Rueschemeyer and T. Skocpol (eds), States, Social Knowledge, and the Origins of Modern Social Policies, Princeton: Princeton University Press, pp. $17-47$.

Klenk, T. and E. Pavolini (2015), 'Conclusions', in T. Klenk and E. Pavolini (eds), Restructuring Welfare Governance. Marketization, Managerialism and Welfare State Professionalism, Cheltenham, UK and Northampton, MA, USA: Edward Elgar Publishing, pp. 253-66.

Marshall, T.H. (1950), Citizenship and Social Class, London: Pluto Press.

Mätzke, M. (2011), 'Staatsbürger als Wirtschaftssubjekte und als demografische Ressource. Die Ziele staatlicher Akteure in der Sozialpolitik', Leviathan, 39 (3), 385-406.

Noordegraaf, M. (2015), 'New governance and professionalism', in T. Klenk and E. Pavolini(eds), Restructuring Welfare Governance. Marketization, Managerialism and Welfare State Professionalism, Cheltenham, UK and Northampton, MA, USA: Edward Elgar Publishing, pp. 121-44.

Pierson, P. (2000), 'Increasing returns, path dependence, and the study of politics', American Political Science Review, 94 (2), 251-68.

Pierson, P. (2007), 'The rise and reconfiguration of activist government', in P. Pierson and T. Skocpol (eds), The Transformation of American Politics. Activist Government and the Rise of Conservatism, Princeton: Princeton University Press, pp. 19-38.

Rathmayr, B. (2014), Armut und Fürsorge. Einführung in die Geschichte der Sozialen Arbeit von der Antike bis zur Gegenwart, Opladen and Berlin, Germany and Toronto, Canada: Verlang Barbara Budrich.

Rothstein, B. (1998), Just Institutions Matter: The Moral and Political Logic of the Universal Welfare State, Cambridge, UK and New York, USA: Cambridge University Press.

Sachße, C. (1994), 'Subsidiarität: Zur Karriere eines sozialpolitischen Ordnungsbegriffs', Zeitschrift für Sozialreform, 40 (11), 717-38.

Sachße, C. (2011), 'Zur Geschichte Sozialer Dienste in Deutschland', in A. Evers (ed.), Handbuch Soziale Dienste, Wiesbaden: VS Verlag für Sozialwissenschaften/ Springer Fachmedien, pp. 94-116.

Sachße, C. and F. Tennstedt (1986), 'Sicherheit und Disziplin: Eine Skizze zur Einführung', in C. Sachße and F. Tennstedt (eds), Soziale Sicherheit und Soziale Disziplinierung. Beiträge zu einer Historischen Theorie der Sozialpolitik, Frankfurt am Mein: Suhrkamp, pp. 11-44.

Schimank, U. (2015), "New public management" as de-professionalization conceptual reflections with some applications to school teachers', in T. Klenk and E. Pavolini (eds), Restructuring Welfare Governance. Marketization, Managerialism and Welfare State Professionalism, Cheltenham, UK and Northampton, MA, USA: Edward Elgar Publishing, pp. 183-99.

Sirovátka, T. (2016), 'Factors shaping employment in social services', in T. Sirovátka and B. Greve (eds), Innovation in Social Services. The Public-Private Mix in Service Provision, Fiscal Policy and Employment, London, UK and New York, USA: Routledge, pp. 91-112.

Sirovátka, T. and B. Greve (2016a), 'Comparing the national cases', in T. Sirovátka and B. Greve (eds), Innovation in Social Services. The Public-Private Mix in 
Service Provision, Fiscal Policy and Employment, London, UK and New York, USA: Routledge, pp. 201-26.

Sirovátka, T. and B. Greve (2016b), 'Social services and the public sector', in T. Sirovátka and B. Greve (eds), Innovation in Social Services. The Public-Private Mix in Service Provision, Fiscal Policy and Employment, London, UK and New York, USA: Routledge, pp. 9-20.

Somers, M. (2008), Genealogies of Citizenship. Markets, Statelessness, and the Right to Have Rights, Cambridge, UK and New York, USA: Cambridge University Press.

Soss, J. (2005), 'Making clients and citizens: welfare policy as a source of status, belief, and action', in A.L. Schneider and H.M. Ingram (eds), Deserving and Entitled. Social Constructions and Public Policy, Albany: SUNY Press, pp. 291-328.

Spicker, P. (2013), Reclaiming Individualism. Perspectives on Public Policy, Bristol: Policy Press.

Steinmetz, G. (1993), Regulating the Social. The Welfare State and Local Politics in Imperial Germany, Princeton: Princeton University Press. 